\title{
Curcumin rescues breast cells from epithelial-mesenchymal transition and invasion induced by anti-miR-34a
}

\author{
MARCELA GALLARDO $^{1}$, ULRIKE KEMMERLING ${ }^{2}$, FRANCISCO AGUAYO ${ }^{1,3,4}$, \\ TAMMY C. BLEAK ${ }^{1}$, JUAN P. MUÑOZ ${ }^{1}$ and GLORIA M. CALAF ${ }^{1,5}$ \\ ${ }^{1}$ Instituto de Alta Investigación, Universidad de Tarapacá, Arica 1001236; ${ }^{2}$ Programa de Anatomía y Biología del \\ Desarrollo ICBM, Facultad de Medicina, Universidad de Chile, Santiago 8380000; ${ }^{3}$ Programa de Virología, \\ Instituto de Ciencias Biomédicas, Facultad de Medicina, Universidad de Chile, Santiago 8380000; \\ ${ }^{4}$ Advanced Center for Chronic Diseases (ACCDiS), Universidad de Chile, Santiago 8380000, Chile; \\ ${ }^{5}$ Center for Radiological Research, Columbia University Medical Center, New York, NY 10032, USA
}

Received October 29, 2018; Accepted September 23, 2019

DOI: $10.3892 /$ ijo.2019.4939

\begin{abstract}
Breast cancer is the most prevalent type of cancer among women worldwide and it is characterized by a high morbidity. Curcumin is a naturally occurring compound derived from the rhizome of Curcuma longa and is known to have antioxidant and anticarcinogenic properties. Emerging evidence has indicated that microRNAs (miRNAs or miRs) function as oncogenes or tumor suppressor genes to control invasion and migration. The aim of this study was to evaluate the effects of curcumin on genes implicated in epithelial-mesenchymal transition (EMT) and to examine the involvement of Rho-A in the migration and invasion of MCF-10F and MDA-MB-231 breast cell lines. Furthermore, to the best of our knowledge, this is the first study to examine the effects of curcumin on Rho-A and on genes involved in EMT, such as $A x l$, Slug and $C D 24$ in order to determine whether the compound is able to prevent migration and invasion by targeting miRNAs as a regulator of such genes. Specifically, we focused on miR-34a which acts as a tumor suppressor gene in human breast cell lines. The present study demonstrated that the Axl, Slug and CD24 genes were implicated in EMT, and $R h o-A$ was also involved in the migration and invasion of MCF-10F and MDA-MB-231 cell lines. Curcumin also acted upon the miRNA as a regulator of genes implicated in EMT and upon Rho-A as well, affecting the migration and invasion of the cells. This occurred independently of their estrogen receptor (ER), progesterone receptor $(\mathrm{PgR})$ and human epidermal growth factor receptor 2 (HER2) receptors in the non-malignant MCF-10F and malignant MDA-MB-231 breast cell lines, which are both negative for such receptors.
\end{abstract}

Correspondence to: Dr. Gloria M. Calaf, Instituto de Alta Investigación, Universidad de Tarapacá, Calle Antofagasta 1520, Arica 1001236, Chile

E-mail: gmc24@cumc.columbia.edu

Key words: curcumin, miRNA, breast cancer cells

\section{Introduction}

Breast cancer is the most prevalent type of cancer among women worldwide and it is characterized by a high morbidity (1). Metastasis is considered one of the most crucial stages of tumor progression as it accounts for $>90 \%$ of all cancer-related deaths $(2,3)$. There have been notable improvements in survival over the past 3 decades for the majority of cancer types and the 5-year relative survival rate for breast cancer patients has increased from $63 \%$ in the early 1960s to $91 \%$ between 2007 and 2013. However, the survival rate is low among women with more advanced stages of the disease at the time of diagnosis. Thus, the relative survival is $99 \%$ for localized disease, $85 \%$ for regional disease and $27 \%$ for distant-stage disease (4). According to the World Health Organization (WHO), the improvement of the survival of breast cancer patients by early detection remains the foundation of breast cancer regulations.

Epithelial-mesenchymal transition (EMT) is a biological process through which a polarized epithelial cell, which normally interacts with the basement membrane via its basal surface, which endows the cell with the ability to undergo multiple biochemical alterations. These alterations enable the cell to acquire a mesenchymal phenotype; consequently, the cell also acquires an enhanced migratory and invasive capacity, and increased resistance to apoptosis (5).

AXL is a receptor of the TAM family of receptor tyrosine kinases (Tyro3, Axl and Mer). It transduces signals from the extracellular matrix into the cytoplasm by binding to its main ligand, thus inducing dimerization and autophosphorylation and the activation of signaling pathways involved in a wide variety of cellular processes, including survival, proliferation, migration, invasion and EMT (6). AXL is considered to function as an oncogene and is known to be overexpressed in breast, lung, ovarian, gastric, pancreatic and prostate cancers. In addition, AXL is regulated by tumor suppressor microRNAs (miRNAs or miRs), such as miR-34a and it is associated with an enhanced metastatic potential (7), a poor prognosis (8) and resistance to therapy (9) in several types of cancer.

Slug is a $\mathrm{C} 2 \mathrm{H} 2$-type zinc-finger transcription factor and is a member of the Snail family. It is known to play a key role in 
the development of cancer and in cancer-related EMT. The Slug protein binds to E-box motifs in the promoter of downstream genes and has been shown to suppress E-cadherin transcription in breast cancer, gastric cancer and esophageal squamous cell carcinoma $(10,11)$. It has also been demonstrated that Slug is negatively associated with estrogen receptor (ER) $\alpha$ in both breast and lung cancer $(12,13)$.

Cluster of differentiation 24 (CD24) is a small GPI-linked membrane glycoprotein with glycosylation sites that bind P-selectin (14). CD24 is an adhesion molecule, and it has been shown to be widely expressed in a number of types of cancer, including renal, ovarian, lung and pancreatic cancer (15-17). A previous study also suggested that CD24 expression is a candidate marker for the prognosis of patients with breast cancer (18).

Ras homolog gene family member A (Rho-A) is a member of the Ras-related $\mathrm{C} 3$ botulinum toxin substrate (Rac) subfamily of the Rho family and is a small ( 22 kDa) $\mathrm{G}$ protein/guanosine triphosphatase (19). Rho-A can induce the reorganization of the cell cytoskeleton and can regulate cell migration by activating effector proteins, such as Rho-associated coiled-coil kinase (ROCK) (20); these types of alterations are associated with tumor invasion and migration in several types of cancer cells $(21,22)$. In breast cancer, an increased expression of Rho-A has been shown to be associated with cancer progression $(23,24)$. In addition, an increased expression of Rho-A seems to promote an enhanced cell invasion and metastasis (24).

There is evidence to suggest that the expression of miRNAs play a pivotal role in regulating the acquisition of the EMT phenotype (25). miRNAs are endogenous, non-coding RNAs approximately 21-23 nucleotides in length and have been identified as key negative regulators of gene expression through the endogenous RNA interference machinery. miRNAs are able to regulate gene expression by binding to miRNA recognition elements (MREs) located in the 3' untranslated region (3'-UTR) of target messenger RNAs (mRNAs), leading to their translational repression or degradation $(25,26)$. It has been previously demonstrated either that miRNAs function as oncogenes or tumor suppressor genes, depending on their target genes of regulation, in order to control cell proliferation, invasion, migration, differentiation and apoptosis (27). Recently, the abnormal expression of miRNAs in several types of cancer has been confirmed, including colon cancer, hepatocellular carcinoma, lung cancer and breast cancer (28); in these types of cancer, miRNAs have been shown to be associated with tumor progression, invasion, metastasis and angiogenesis $(28,29)$.

miRNAs as tumor suppressors have been found to be overexpressed in a variety of human cancers, contributing to tumor development. miRNA-34a (miR-34a) has been reported to function as tumor suppressor miRNA and has been shown to be downregulated in cancers $(28,29)$; it also plays an important role in tumorigenesis and the progression of cancer (30).

It is known that certain herbs have the ability to regulate miRNAs associated with cancer (31). Among these, curcumin, a naturally occurring compound derived from the rhizome of Curcuma longa, and its analogs are known to exert potent anti-carcinogenic effects (32) through the regulation of multiple downstream cancer-related signaling molecules (33). Studies have demonstrated a protective role of curcumin in the oxidative stress of breast cells $(34,35)$. It has been demonstrated that curcumin affects breast cancer cells transformed by low concentrations of radiation and estrogen (36). Among the genes involved in such processes, CD44 expression has been shown to be associated with oxidative stress in such cells (37). On the other hand, it has been demonstrated that curcumin suppresses the invasive capabilities of breast cancer cell lines through EMT (38).

MDA-MB-231 is a basal-like triple-negative breast cancer cell line. Triple-negative breast cancer [negative for ER, progesterone receptor $(\mathrm{PgR})$ and human epidermal growth factor receptor 2 (HER2)] is the most aggressive breast cancer subtype and is associated with a poor prognosis. The aim of the present study was to determine whether curcumin modulates miRNA expression, whether it induces EMT-related changes, and thereof, whether it affects the motility of breast cells.

\section{Materials and methods}

Breast cell lines. MCF-10F human breast and MDA-MB-231 human breast cancer cell lines were obtained from the American Type Culture Collection (ATCC). The MCF-10F cells were grown in Dulbecco's modified Eagle's medium (DMEM)/F-12 (1:1) supplemented with $100 \mathrm{U} / \mathrm{ml}$ penicillin, $100 \mu \mathrm{g} / \mathrm{ml}$ streptomycin (all obtained from Life Technologies, Thermo Fisher Scientific) and 5\% equine serum (Biofluids), $0.5 \mu \mathrm{g} / \mathrm{ml}$ hydrocortisone (Sigma) and $0.02 \mu \mathrm{g} / \mathrm{ml}$ epidermal growth factor (Collaborative Research). The MDA-MB-231 cells were maintained in RPMI-1640 medium (Life Technologies, Thermo Fisher Scientific) supplemented with penicillin $(100 \mathrm{U} / \mathrm{ml})$, streptomycin $(100 \mu \mathrm{g} / \mathrm{ml}), 0.1 \mathrm{mM}$ non-essential amino acids, $0.2 \mathrm{mM}$ glutamine, $1 \mathrm{mM}$ pyruvate and $10 \%$ heat-inactivated fetal bovine serum, and incubated in a $5 \% \mathrm{CO}_{2}$ humidified atmosphere at $37^{\circ} \mathrm{C}$. The cells were grown to $80 \%$ confluence prior to the treatments.

Cell viability assay. The viability of the cells was determined in the presence of curcumin (Sigma-Aldrich; Merck KGaA). Firstly, the MCF-10F and MDA-MB-231 cell lines were seeded in 96 -well microplates $\left(25 \times 10^{3}\right.$ cells/well) in a final volume of $100 \mu \mathrm{l}$ and incubated in culture medium for $48 \mathrm{~h}$ at $37^{\circ} \mathrm{C}$ and a $5 \%$ concentration of $\mathrm{CO}_{2}$. Following overnight incubation at $37^{\circ} \mathrm{C}$, the cells were treated with $0,5,10,15,20,25$, 30 and $35 \mu \mathrm{M}$ of curcumin. Curcumin was dissolved in $0.1 \%$ of DMSO solvent and used as a blank. Cells not treated curcumin functioned as the control group. Following $48 \mathrm{~h}$ of incubation at $37^{\circ} \mathrm{C}$, the metabolic activity of the living cells was determined by 3-(4,5-dimethyl-2-thiazolyl)-2,5-diphenyl-2H-tetrazolium bromide (MTT) assay (Sigma-Aldrich). The medium was removed, and the insoluble formazan crystals were dissolved in $200 \mu \mathrm{l}$ of DMSO. Subsequently, $20 \mu \mathrm{l}$ MTT $(5 \mathrm{mg} / \mathrm{ml})$ were added to each well. The cells were then incubated at $37^{\circ} \mathrm{C}$ for a further $4 \mathrm{~h}$. The reduction of MTT was determined following the manufacturer's instructions. The absorbance was determined at $570 \mathrm{~nm}$ (Autobio Labtec Instruments) in a microplate reader (Molecular Devices). The results were expressed as the percentage of cell survival relative to the control. The $50 \%$ inhibitory concentration $\left(\mathrm{IC}_{50}\right)$ was defined as the curcumin concentration that induced a $50 \%$ reduction in the viability of the cells compared to control, as previously described (34-39). 
Table I. Sequences of primers used for RT-qPCR.

A. Sequence and annealing temperature of the primers used in the RT-qPCR reactions

\begin{tabular}{|c|c|c|}
\hline Gene name & Primer sequence $^{\mathrm{a}}$ & Annealing temperature \\
\hline \multirow[t]{2}{*}{$A x l$} & F: GTTTGGAGCTGTGATGGAAGGC & 62.01 \\
\hline & R: CGCTTCACTCAGGAAATCCTCC & 61 \\
\hline \multirow[t]{2}{*}{ Slug } & F: GACCCTGGTTGCTTCAAGGA & 59.89 \\
\hline & R: TGTTGCAGTGAGGGCAAGAA & 60.11 \\
\hline \multirow[t]{2}{*}{$C D 24$} & F: AACTAATGCCACCACCAGG & 58.1 \\
\hline & R: GACGTTTCTTGGCCTGAGTC & 58.9 \\
\hline \multirow[t]{2}{*}{ Rho- $A$} & F: CCATCATCCTGGTGGGGAAT & 54.8 \\
\hline & R: CATCCCAAAAGCGCCA & 56.1 \\
\hline
\end{tabular}

B. Alignment of mature miR-200a, miR-200c, let-7a, let-7c, let-7b, miR-21 and miR-34a sequences

\begin{tabular}{lll}
\hline Assay ID & \multicolumn{1}{c}{ miR } & \multicolumn{1}{c}{ Mature sequence $^{\text {b }}$} \\
\hline 000502 & hsa-miR-200a & UAACACUGUCUGGUAACGAUGU \\
000505 & hsa-miR-200c & UAAUACUGCCGGGUAAUGAUGG \\
000377 & hsa-let-7a & UGAGGUAGUAGGUUGUAUAGUU \\
000379 & hsa-let-7c & UGAGGUAGUAGGUUGUAUGGUU \\
000378 & hsa-let-7b & UGAGGUAGUAGGUUGUGUGGUU \\
000397 & hsa-miR-21 & UAGCUUAUCAGACUGAUGUUGA \\
000425 & hsa-miR-34a & UGGCAGUGUCUUAGCUGGUUGU \\
\hline
\end{tabular}

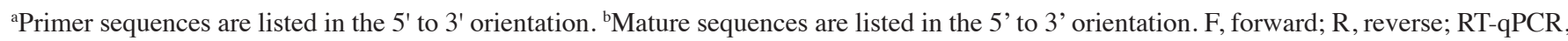
reverse transcription-quantitative polymerase chain reaction.

RNA extraction and cDNA synthesis. For RNA isolation, two separate purification procedures were carried out. The measurement of small RNA (containing miRNA) and larger RNA (containing mRNA) from the cells was determined using the RNeasy Plus Mini kit (cat. no. 74204) and the Rneasy MinElute Cleanup kit (cat. no. 74134), according to the manufacturer's instructions (Qiagen). For mRNAs, $2 \mu \mathrm{g}$ of the longer RNA fraction were reverse transcribed into cDNA using the High Capacity cDNA Reverse Transcription kit (Applied Biosystems). For miRNAs, reverse transcription was carried out using 2 to $10 \mathrm{ng}$ of the small RNA fraction, the TaqMan ${ }^{\circledR}$ MicroRNA Reverse Transcription kit (cat. no. 4366596; Applied Biosystems) and gene-specific RT-primers according to the TaqMan MicroRNA assay protocol (cat. no. 4427975; Applied Biosystems).

$R T$-qPCR for the analysis of $m R N A$ expression. RNA was obtained using RNeasy Plus Mini kit and RNeasy MinElute kit (Qiagen) following the manufacturer's protocol and for reverse transcription the High capacity cDNA Reverse Transcription (Applied Biosystems). An aliquot of a dilution 1/50 of cDNA $(2 \mu \mathrm{l})$ was used in a $20 \mu \mathrm{l}$ qPCR reaction containing SYBR-Green PCR Master Mix (Agilent Technologies) and 5 $\mu \mathrm{M}$ of each primer for the target genes, such as Axl, Slug, CD24 and Rho-A. The primers for the selected genes are presented in Table IA. The reaction was carried out on a CFX 96 Touch Real-Time PCR Detection System (Bio-Rad Laboratories) with the following conditions: $95^{\circ} \mathrm{C}$ for $10 \mathrm{~min}$ and 40 cycles of a 2-step program of $95^{\circ} \mathrm{C}$ for $10 \mathrm{sec}$ and $61^{\circ} \mathrm{C}$ for $45 \mathrm{sec}$ when fluorescence-reading occurs. The reactions were carried out in triplicate and the threshold of the cycle was obtained using Bio-Rad CFX Manager 2.1 software and the average gene expression was normalized using the reference housekeeping gene $\beta$-actin and the relative expression level was calculated as previously described $(36,38)$, using the $2^{-\Delta \Delta C q}$ method (40).

$R T-q P C R$ for the analysis of miRNA expression. It was done by using RNeasy Plus Mini kit and RNeasy MinElute Cleanup kit (Qiagen) according to the manufacturer's protocol. An aliquot of cDNA $(2 \mu \mathrm{l})$ was used in $15 \mu \mathrm{l}$ qPCR reaction containing TaqMan Small RNA Assays specific for each miRNA (cat. no. 4427975) and TaqMan Universal PCR Master Mix II (cat. no. 4440040; Applied Biosystems). The alignment of mature miR-200a, miR-200c, let-7a, let-7c, let-7b, miR-21 and miR-34a sequences is presented in Table IB. The reaction was carried out on a CFX 96 Touch Real-Time PCR Detection Systems (Bio-Rad Laboratories) with the following conditions; $50^{\circ} \mathrm{C}$ for $2 \mathrm{~min}, 95^{\circ} \mathrm{C}$ for $10 \mathrm{~min}$ and 40 cycles of a 2-step program of $95^{\circ} \mathrm{C}$ for $15 \mathrm{sec}$ and $60^{\circ} \mathrm{C}$ for $60 \mathrm{sec}$ when fluorescence-reading occurs. The reactions were carried out in triplicate and the threshold of the cycle was obtained using Bio-Rad CFX Manager 2.1 software and the average gene expression was normalized using the reference snRNA U6. The relative expression of each miRNA was normalized against 


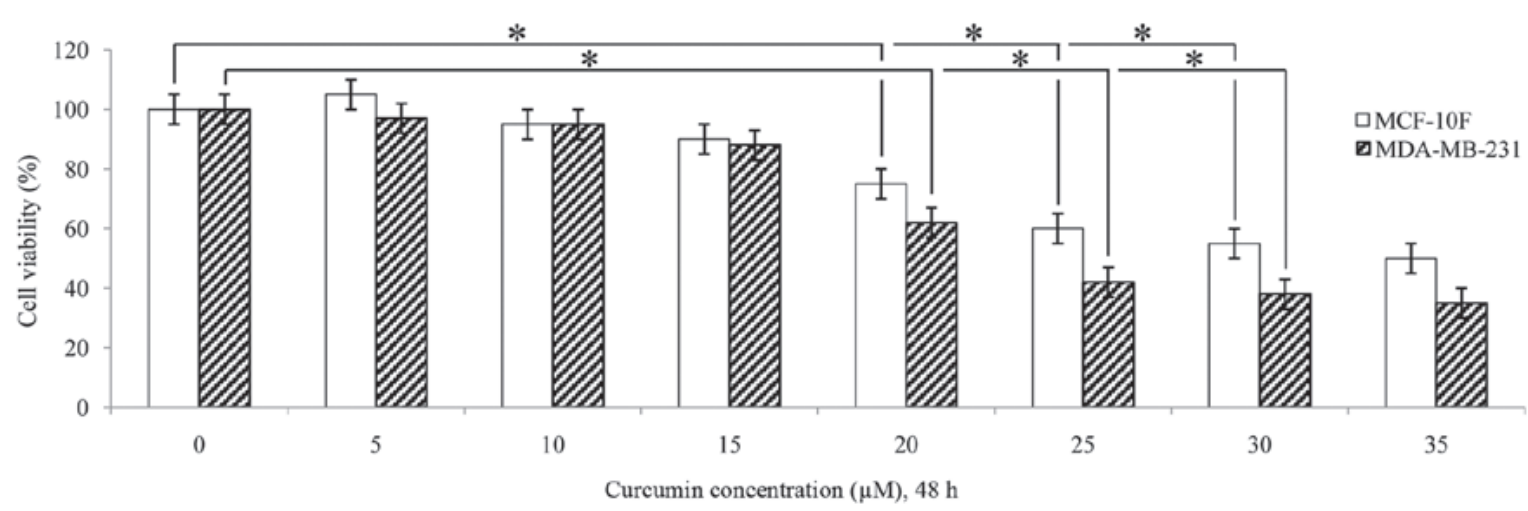

Figure 1. Cell viability assay by MTT. MCF-10F and MDA-MB-231 cell lines cultured in the presence of curcumin from 0 to $35 \mu \mathrm{M}$ for IC 50 determination $(\mathrm{n}=3)(\mathrm{P}<0.05)$.

snRNA U6 (ID no. 001973) expression using a Bio-Rad CFX Manager 2.1 software.

Oligonucleotide transfection. The MCF-10F and MDA-MB-231 cells were transfected with 75 pmol anti-miR-34a (cat. no. AM11030) or anti-miR negative control (cat. no. AM17010) (Life Technologies, Thermo Fisher Scientific) using Lipofectamine ${ }^{\circledR} 2000$ (Invitrogen, Thermo Fisher Scientific) according to the manufacturer's instructions. The cells were assayed 24,48 or $72 \mathrm{~h}$ post-transfection.

Cell migration and invasion assays. Migration and invasion assays were performed using modified Boyden's chambers (Corning, Inc.) constructed with multiwall cell culture plates and cell culture inserts as previously described $(36,38)$. For the invasion assay, the upper chambers of Transwells with $8-\mu \mathrm{m}$ membrane pores were pre-coated with Matrigel matrix gel $(60 \mu \mathrm{l})$ (BD Biosciences) at least $1 \mathrm{~h}$ prior to the seeding of the tested cells. The cells were pre-treated with curcumin $(30 \mu \mathrm{M})$ and cultured for $24 \mathrm{~h}$. A total of $3 \times 10^{5}$ cells in $100 \mu \mathrm{l}$ of medium without fetal bovine serum was added to the upper chambers and $600 \mu \mathrm{l}$ of medium with $10 \%$ FBS was placed in the lower chambers as a chemoattractant. The Matrigel invasion chamber was incubated for $16 \mathrm{~h}$ in a humidified tissue culture incubator. The upper chambers were then removed from the lower chambers and then wiped using cotton swabs. The invaded and migrated cells were fixed using $100 \%$ methanol at room temperature for $15 \mathrm{~min}$, visualized and quantified using DAPI. Ten fields of each chamber were photographed using a fluorescence microscope (x40 magnification, Olympus Corp.). Migration assay was carried out the same way as the invasion assay; however, the Transwell insert was not coated with Matrigel. This experiment was independently repeated 3 times.

Protein expression by immunoperoxidase staining. Exponentially growing cells were plated on a glass chamber slide (Nunc Inc.) at a density of $1 \times 10^{4}$ cells $/ \mathrm{ml}$ of medium and allowed to grow for 2-3 days until $70 \%$ confluent as previously described (39). The cells were then fixed with buffered paraformaldehyde at room temperature, incubated with $1 \% \mathrm{H}_{2} \mathrm{O}_{2}$ in methanol to block endogenous peroxidase and washed again twice with buffer solution. Subsequently, the cell cultures were then covered with normal horse serum for $30 \mathrm{~min}$ at room temperature and incubated with either anti-mouse or anti-goat monoclonal or polyclonal antibodies: Anti-Axl (mouse, sc-166269), anti-Slug (mouse, sc-166476), anti-CD24 (mouse, sc-65257) and anti-Rho-A (mouse, sc-418), (all from Santa Cruz Biotechnology, Inc.) at a 1:500 dilution overnight at $4^{\circ} \mathrm{C}$. The cells were subsequently incubated for $45 \mathrm{~min}$ with diluted biotinylated secondary antibody solution (Vector Laboratories Inc.) and Vectastin Elite ABC reagent (Vector Laboratories Inc.) was used. The experiments were repeated twice in cells with identical passages in vitro. A semi-quantitative estimation based on the relative staining intensity of protein expression both in the untreated control and treated cells was determined. The number of immunoreactive cells (30 cells/field) was counted in 5 randomly selected microscopy fields per sample and the percentage of relative fold protein expression was calculated.

Statistical analysis. Numerical data are expressed as the means \pm standard error of the mean (SEM). Comparisons between 2 groups were made using the t-test and between several treatment groups and the controls by ANOVA with Dunnett's test. Data were analyzed using release IBM SPSS 22.0 (SPSS, Inc.). A value of $\mathrm{P}<0.05$ was considered to indicate a statistically significant difference.

\section{Results}

Cell viability of the cells following treatment with curcumin. Cell viability assay was performed using MTT assay to examine the effects of curcumin at various concentrations (fluctuating from 0 to $35 \mu \mathrm{M}$ for $48 \mathrm{~h}$ ) on the viability of the MCF-10F and MDA-MB-231 cells. As shown in Fig. 1, a significant $(\mathrm{P}<0.05)$ decrease in cell viability was observed in both cell lines following treatment with 20 and $30 \mu \mathrm{M}$ curcumin for $48 \mathrm{~h}$ in comparison to the untreated cells $(0 \mu \mathrm{M})$. The concentrations of 10 and $30 \mu \mathrm{M}$ curcumin were used in several experiments.

Effects of curcumin on MCF-10F gene and protein expression levels. As shown in Fig. $2 \mathrm{~A}$, curcumin $(30 \mu \mathrm{M}$ for $48 \mathrm{~h})$ significantly $(\mathrm{P}<0.05)$ decreased the Axl (39\%), Slug (57\%), CD24 (62\%) and Rho-A (53\%) gene transcript levels. In addition, 
MCF-10F cell line (48 h)

A

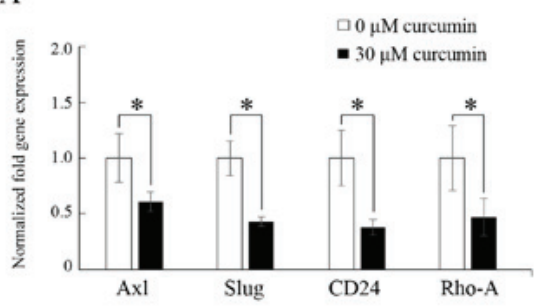

C Protein expression

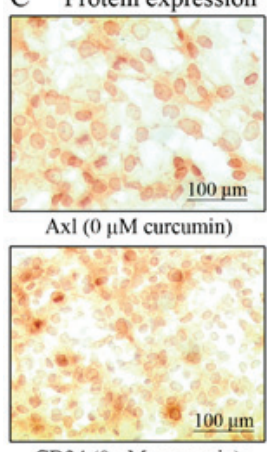

$\mathrm{CD} 24(0 \mu \mathrm{M}$ curcumin $)$

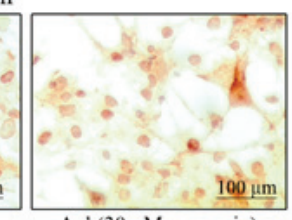

$\operatorname{Axl}(30 \mu \mathrm{M}$ curcumin)

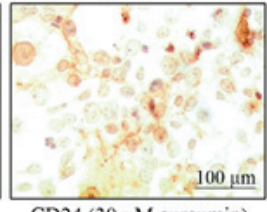

B

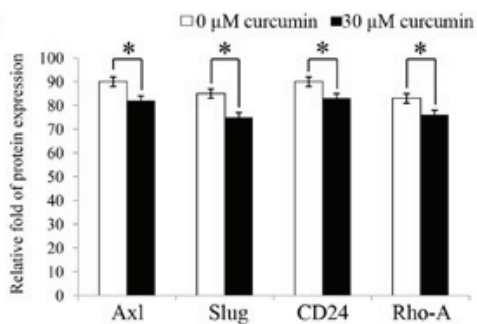

Figure 2. Graphs showing the effects of curcumin ( $30 \mu \mathrm{M}$ for $48 \mathrm{~h}$ ) on $A x l$, Slug, CD24, and Rho-A expression in the MCF-10 cell line. (A) Normalized fold gene transcript levels by RT-qPCR, and (B) relative protein expression (\%) by immunocytochemistry in comparison to their own controls. Bars in the figure indicate the means \pm standard error of the mean $\left(n=3 ;{ }^{*} \mathrm{P}<0.05\right)$. (C) Representative images of the effects of curcumin on protein expression levels in comparison to their own controls.
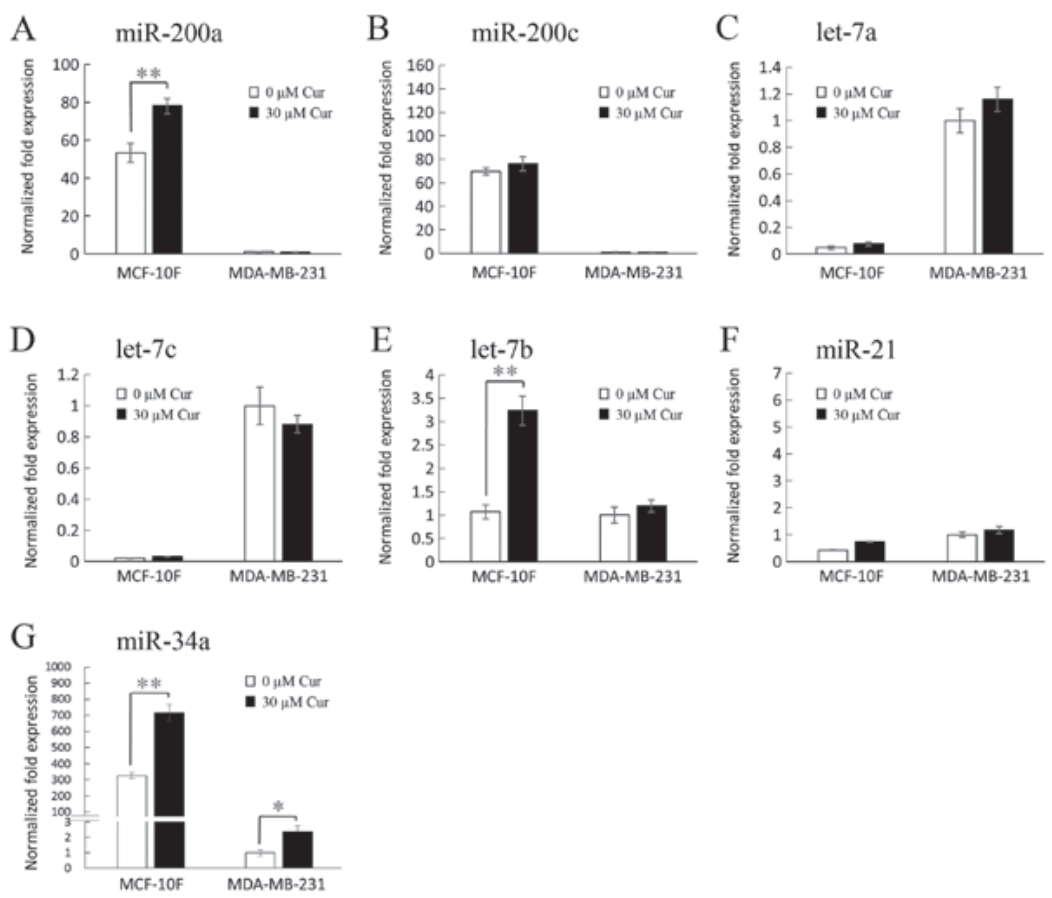

Figure 3. Effects of curcumin (Cur) (30 $\mu \mathrm{M}$ for $48 \mathrm{~h}$ ) on (A) miR-200a, (B) miR-200c, (C) let-7a, (D) let-7c, (E) let-7b, (F) miR-21 and (G) miR-34a expression examined by RT-qPCR in the MCF-10F and MDA-MB-231 breast cell lines. Graphs show the fold change in miRNA expression in cells treated with Cur in comparison to their own controls. Bars in the figure indicate the means \pm standard error of the mean $\left(\mathrm{n}=3 ;{ }^{*} \mathrm{P}<0.05,{ }^{* * *} \mathrm{P}<0.005\right)$.

protein expression was examined by immunocytochemistry in MCF-10F cell line in comparison to its own controls (Fig. 2B). Similar to the mRNA levels, curcumin also induced a decrease in the protein levels of Axl, Slug, CD24 and Rho-A in the cells. Representative images of the effects of curcumin on protein expression levels are presented in Fig. 2C.
Effects of curcumin on miRNA levels. As shown in Fig. 3, treatment with $30 \mu \mathrm{M}$ curcumin significantly $(46 \%, \mathrm{P}<0.05)$ increased miR-200a expression in the MCF-10F cell line in comparison with its own control (Fig. 3A); however, it had no marked effect on the MDA-MB-231 cell line. In addition, curcumin did not exert any notable effects on the expression 


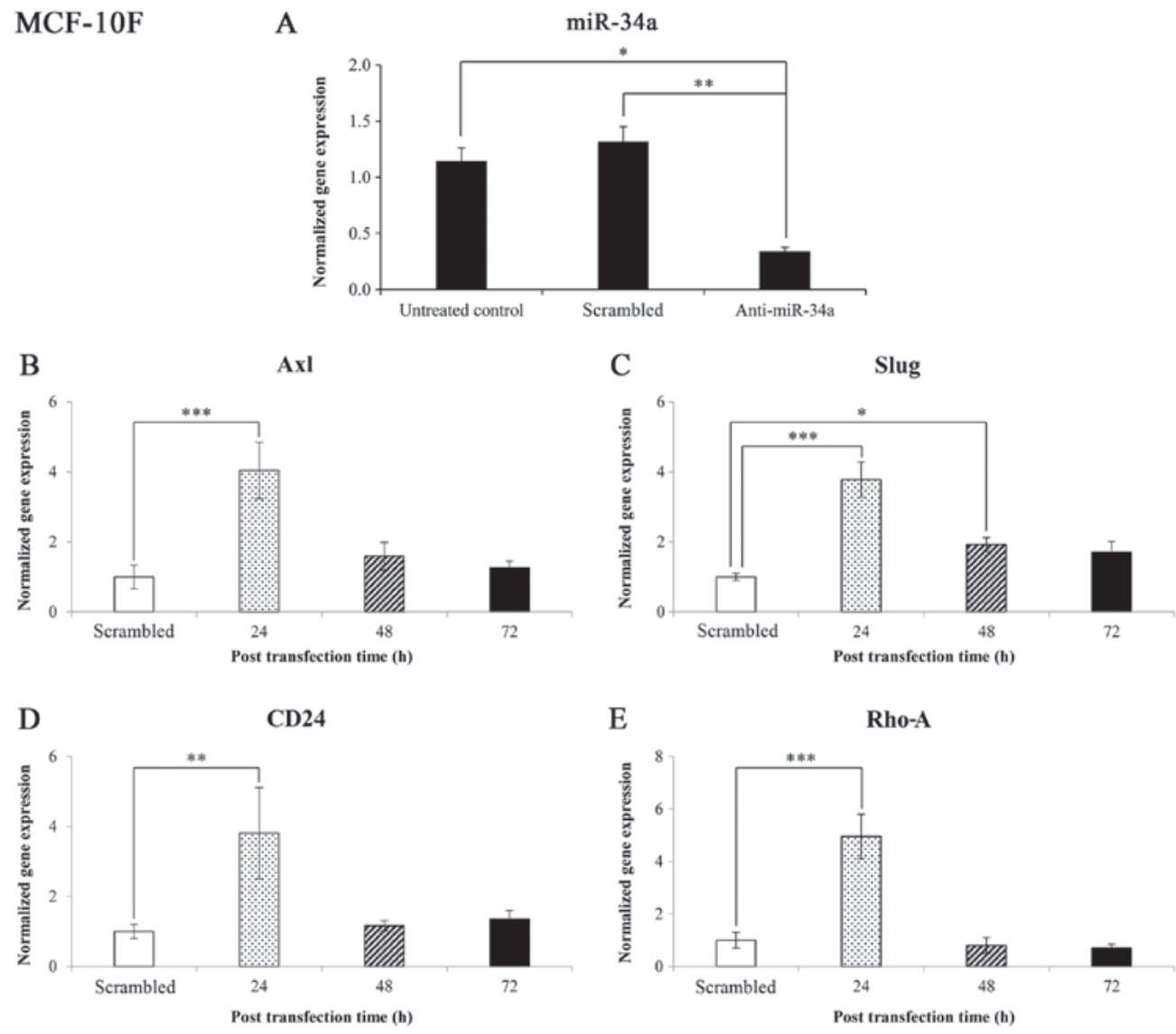

Figure 4. (A) Graph showing the fold change of miR-34a expression in the MCF-10F cell line in comparison to the untreated control and negative control (scrambled). (B-E) Graphs represent the effects of the time of post-transfection with anti-miR-34a in the MCF-10F cell line on (B) Axl, (C) Slug, (D) CD24 and (E) Rho-A normalized gene expression after 24,48 and $72 \mathrm{~h}$. Bars represent the means \pm standard error of the mean $\left(\mathrm{n}=3 ;{ }^{*} \mathrm{P}<0.05,{ }^{* * *} \mathrm{P}<0.005,{ }^{* * * *} \mathrm{P}<0.001\right)$.

levels of miR-200c (Fig. 3B), let-7a (Fig. 3C), let-7c (Fig. 3D) and miR-21 (Fig. 3F) in the MCF-10F and MDA-MB-231 cell lines; however, it significantly $(\mathrm{P}<0.05)$ increased let-7b expression (202\%) in the MCF-10F cell line in comparison to its own control (Fig. 3E), although no notable effect was observed on the MDA-MB-231 cell line. On the other hand, as shown in Fig. 3G, curcumin significantly increased miR-34a expression in both the MCF-10F and MDA-MB-231 cell lines $(\mathrm{P}<0.005,120 \%$ and $\mathrm{P}<0.05,138 \%$, respectively), when compared to their own controls.

Effects of anti-miR-34a and the time of post-transfection on gene expression levels in the MCF-10F cell line. The results of the miR-34a expression level in the MCF-10F cell line transfected with anti-miR-34a and negative control (scrambled) are shown in Fig. 4A. The results revealed that miR-34a expression significantly $(\mathrm{P}<0.005$ and $\mathrm{P}<0.05)$ decreased in those cells transfected with anti-miR-34a compared to the scrambled and untreated control, respectively. The normalized gene expression levels following transfection with anti-miR-34a of genes that code for proteins involved in EMT in the MCF-10F cell line are shown in Fig. 4B-E. The effect of blocking miR-34a on Axl, Slug, CD24, and Rho-A gene expression was analyzed. The knockdown of miR-34a significantly $(\mathrm{P}<0.001)$ increased Axl (304\%) expression after $24 \mathrm{~h}$; no significant changes were observed after 48 and 72 h (Fig. 4B). The knockdown of miR-34a also significantly increased Slug expression after
24 and $48 \mathrm{~h}(278 \%, \mathrm{P}<0.001$; and $92 \%, \mathrm{P}<0.05$, respectively) (Fig. 4C). Following the knockdown of miR-34a, an increase was also observed in the CD24 (281\%, P<0.005) (Fig. 4D) Rho-A (395\%, $\mathrm{P}<0.001)$ (Fig. 4E) expression levels following $24 \mathrm{~h}$ of transfection.

Effect of curcumin and anti-miR-34a on gene expression levels in the MCF-10F cell line. The effects of treatment with $30 \mu \mathrm{M}$ curcumin for $48 \mathrm{~h}$ on the Axl, Slug, CD24 and Rho-A gene expression levels in the MCF-10F cell line are shown in Fig. 5. The results revealed that curcumin significantly $(\mathrm{P}<0.05)$ decreased Axl (65\%), Slug (50\%), CD24 (62\%), and Rho-A (55\%) gene expression following transfection of the cells with negative control (scrambled) in comparison with the curcumin-untreated cells. Transfection with anti-miR-34a significantly $(\mathrm{P}<0.05)$ increased the gene expression of Axl (133\%), Slug (290\%), CD24 (282\%) and Rho-A (380\%); however, treatment with curcumin plus anti-miR-34a significantly $(\mathrm{P}<0.05)$ decreased the levels of the examined genes in comparison to the cells transfected with anti-miR-34a and not treated with curcumin (Fig. 5).

Effects of curcumin on the migratory and invasive capabilities of the MCF-10F cell line. The migratory and invasive capabilities were analyzed by migration and invasion assays carried out in a Boyden chamber (Fig. 6A and B). The results presented in Fig. 6A revealed that curcumin significantly $(\mathrm{P}<0.001)$ 

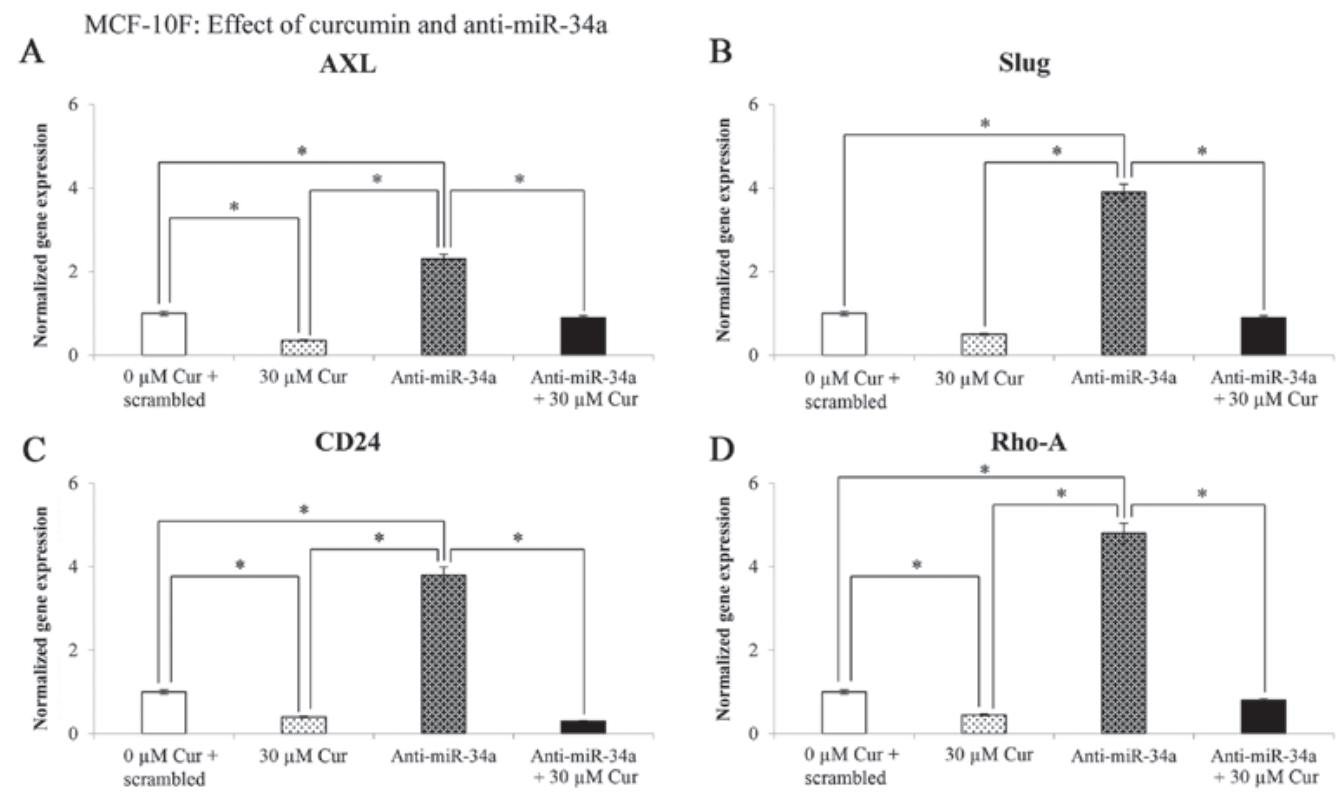

Figure 5. Graphs showing the effects of curcumin (Cur) (30 $\mu \mathrm{M}$ for $48 \mathrm{~h}$ ) on (A) Axl, (B) Slug, (C) CD24 and (D) Rho-A normalized gene expression, and the transfection with anti-miR 34a analyzed by RT-qPCR. Bars in the figure indicate the means \pm standard error of the mean $\left(\mathrm{n}=3\right.$; $\left.{ }^{*} \mathrm{P}<0.05\right)$.

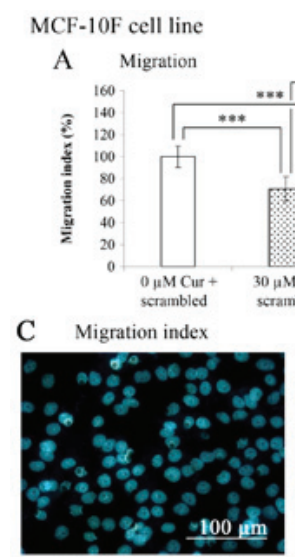

Cur $(0 \mu \mathrm{M})+$ scrambled

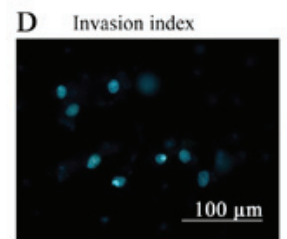

Cur $(0 \mu \mathrm{M})+$ Scrambled

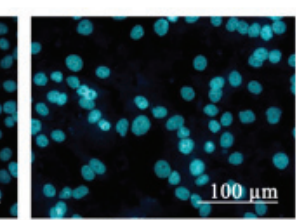

Cur $(30 \mu \mathrm{M})+$ scrambled

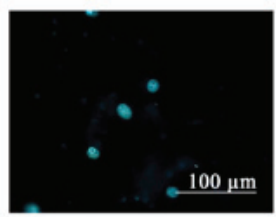

Cur $(30 \mu \mathrm{M})+$ scrambled
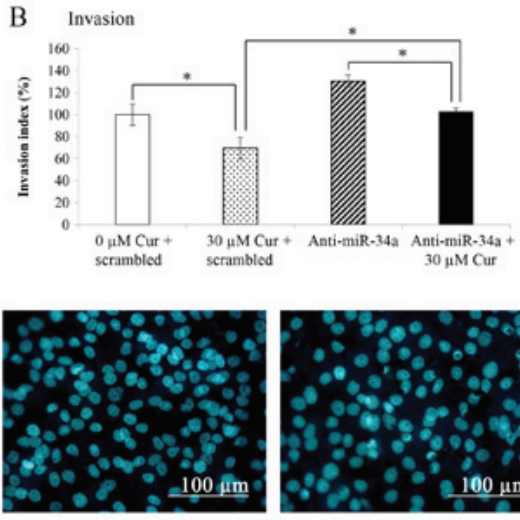

Anti-miR-34a

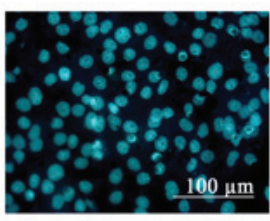

Anti-miR-34a + Cur $(30 \mu \mathrm{M})$

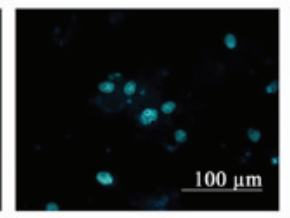

Anti-miR-34a

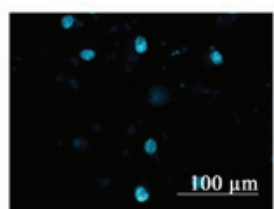

Anti-miR-34a + Cur $(30 \mu \mathrm{M})$

Figure 6. Graphs showing the effects of curcumin (Cur) (30 $\mu \mathrm{M}$ for $48 \mathrm{~h}$ ) and Anti-miR-34a on (A) migration (B) invasion in the MCF-10F cell line (\%). Bars represent the means \pm standard error of the mean $\left(n=3 ;{ }^{*} \mathrm{P}<0.05,{ }^{* *} \mathrm{P}<0.005,{ }^{* * *} \mathrm{P}<0.001\right)$. Representative images are shown of the $(\mathrm{C})$ migration index and (D) invasion index.

decreased the migration $(29.3 \%)$ of the MCF-10F cells transfected with the negative control (scrambled) in comparison with the untreated control cells (scrambled $+0 \mu \mathrm{M}$ Cur). In addition, a significant increase $(24 \%, \mathrm{P}<0.001)$ in the migration of the MCF-10F cells transfected with anti-miR-34a in comparison with the untreated control cells (scrambled $+0 \mu \mathrm{M}$ Cur) was observed. Curcumin plus anti-miR-34a significantly $(\mathrm{P}<0.005)$ decreased the migration of the MCF-10F cell line in comparison to anti-miR-34a alone. The percentage of migrated cells treated with curcumin plus anti-miR-34a was similar to the untreated control (scrambled $+0 \mu \mathrm{M}$ Cur) following trans- fection. When miR-34a was blocked, the migratory capability of the cells decreased.

The effects of the knockdown of miR-34a on the invasive ability of the MCF-10F cells were also evaluated. As shown in Fig. 6B, curcumin significantly $(\mathrm{P}>0.05)$ decreased the invasion $(30.5 \%)$ of the MCF-10F cells transfected with the negative control (scrambled) in comparison with the untreated control cells (scrambled $+0 \mu \mathrm{M}$ Cur). The invasive ability was significantly $(\mathrm{P}<0.05)$ decreased $(39.1 \%)$ in the MCF-10F cells transfected with anti-miR-34a and treated with curcumin compared with anti-miR-34a alone. Cell invasion decreased 

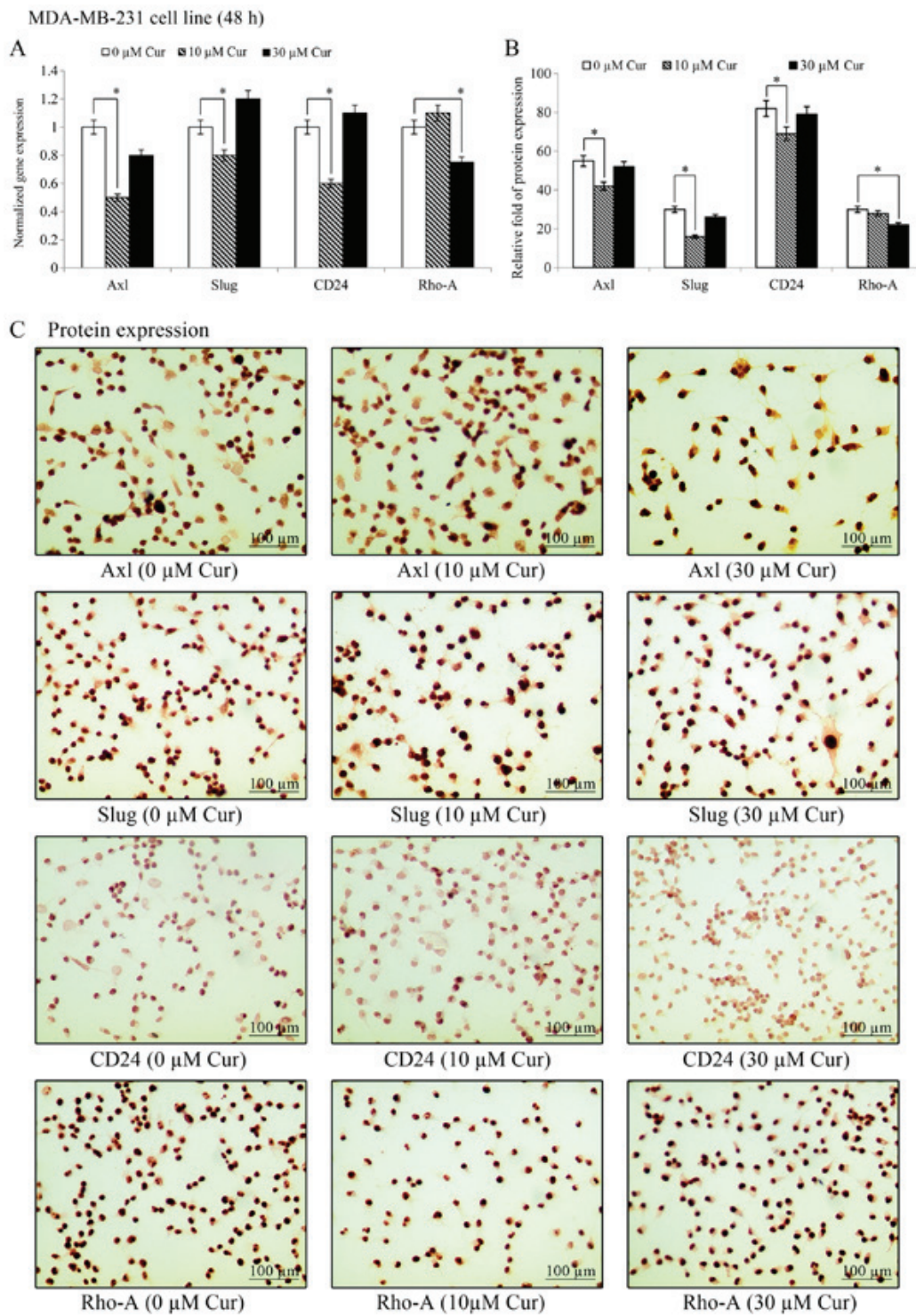

Figure 7. Graphs showing the effect of curcumin (Cur) (10 and $30 \mu \mathrm{M}$ for $48 \mathrm{~h}$ ) on Axl, Slug, CD24 and Rho-A in the MDA-MB-231 cell line. (A) Normalized fold gene transcript levels examined by RT-qPCR and (B) relative protein expression (\%) examined by immunocytochemistry in comparison to their own controls. Bars represent the means \pm standard error of the mean $\left(n=3 ;{ }^{*} P<0.05\right)$. (C) Representative images of the effects of Cur on protein expression levels.

to the level of the untreated control (scrambled $+0 \mu \mathrm{M}$ Cur) when miR-34a was blocked and the cells were treated with curcumin (30 $\mu \mathrm{M}$ for $24 \mathrm{~h}$ ). Representative images of the migratory capabilities following treatment with curcumin and miR-34a blockage in the MCF-10F cell line are shown in Fig. $6 \mathrm{C}$. In addition, representative images of the invasive capabilities following treatment with curcumin and miR-34a blockage are shown in Fig. 6D.

Effects of curcumin on gene and protein expression levels in the MDA-MB-231 cell line. The effects of treatment with 10 and $30 \mu \mathrm{M}$ curcumin on $A x l$, Slug and CD24 gene expression on the MDA-MB-231 cell line are presented in Fig. 7. The results revealed that treatment with $10 \mu \mathrm{M}$ curcumin significantly $(\mathrm{P}<0.05)$ decreased the gene transcript levels of $A x l$, Slug and CD24, while those of Rho-A remained unaffected. However, treatment with $30 \mu \mathrm{M}$ curcumin decreased the Rho-A transcript levels, while those of the other genes were unaffected. As shown in Fig. 7B, treatment with $10 \mu \mathrm{M}$ curcumin decreased the Axl, Slug, and CD24 protein expression levels in the MDA-MB-231 cell line; however, the levels of Rho-A were unaffected by this concentration. However, treatment with $30 \mu \mathrm{M}$ curcumin decreased only Rho-A protein expression in comparison to its own control. Representative images of the effects of curcumin on protein expression levels in the MDA-MB-231 cell line are shown in Fig. 7C. The results revealed that treatment with $10 \mu \mathrm{M}$ curcumin decreased Axl, Slug and CD24 protein expression. However, $30 \mu \mathrm{M}$ curcumin decreased only Rho-A protein expression in comparison to its own control.

Effects of anti-miR-34a and the time of post-transfection on gene expression levels in the MDA-MB-231 cell line. The results of the miR-34a expression level in the MDA-MB-231 cell line in comparison to the untreated control and negative control (scrambled) are presented in Fig. 8A. The results indicated that miR-34a expression significantly decreased $(\mathrm{P}<0.05)$ in the anti-miR-34a-transfected cells compared to the 

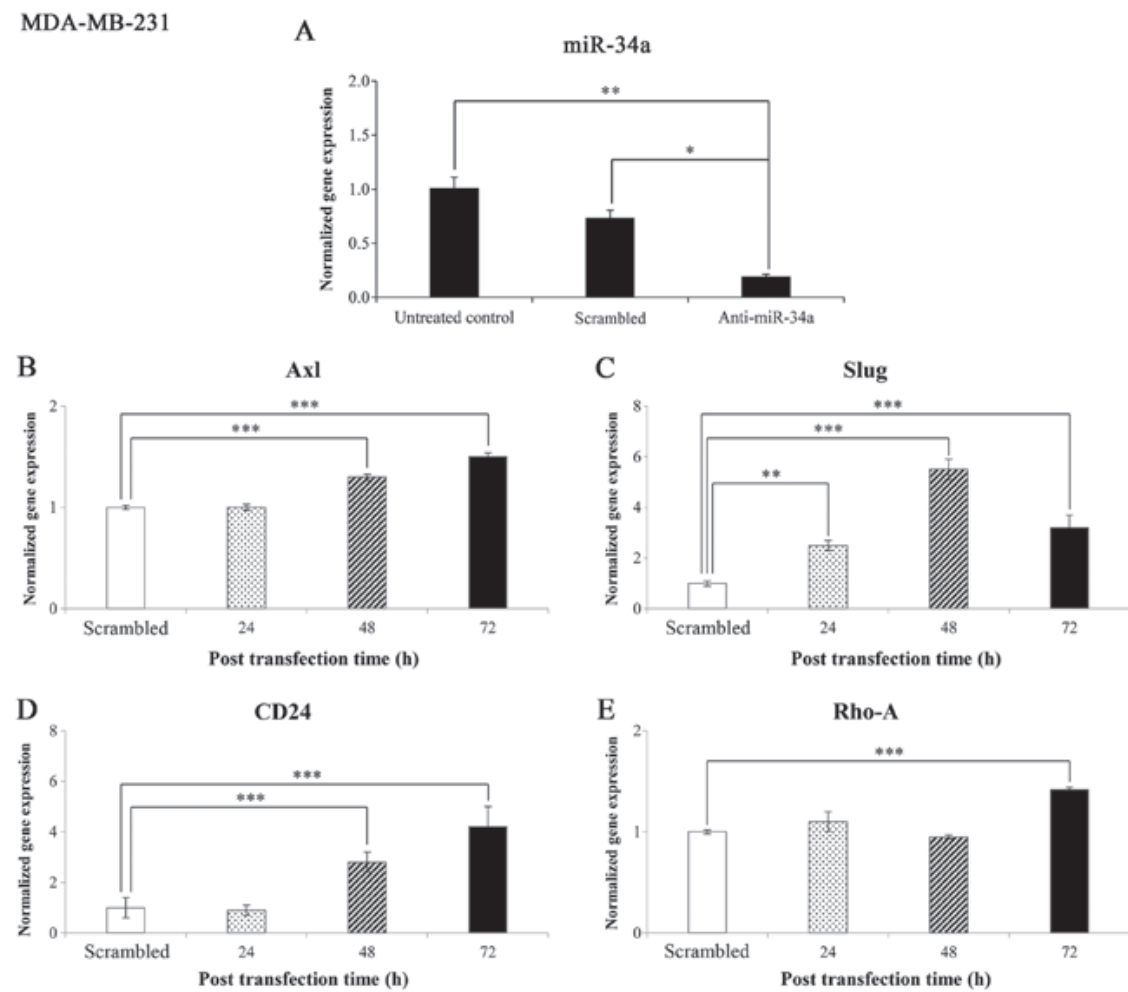

Figure 8. (A) Graph showing the fold change in miR-34a expression in the MDA-MB-231 cell line in comparison to the untreated cells and negative control (scrambled). (B-E) Graphs showing the effects of the time of post-transfection with Anti-miR-34a on (B) Axl, (C) Slug, (D) CD24 and (E) Rho-A normalized gene expression after 24,48 and $72 \mathrm{~h}$ in the same cell line. Bars in the figure indicate means \pm standard error of the mean $\left(\mathrm{n}=3 ;{ }^{*} \mathrm{P}<0.05,{ }^{* *} \mathrm{P}<0.005,{ }^{* * * *} \mathrm{P}<0.001\right)$.
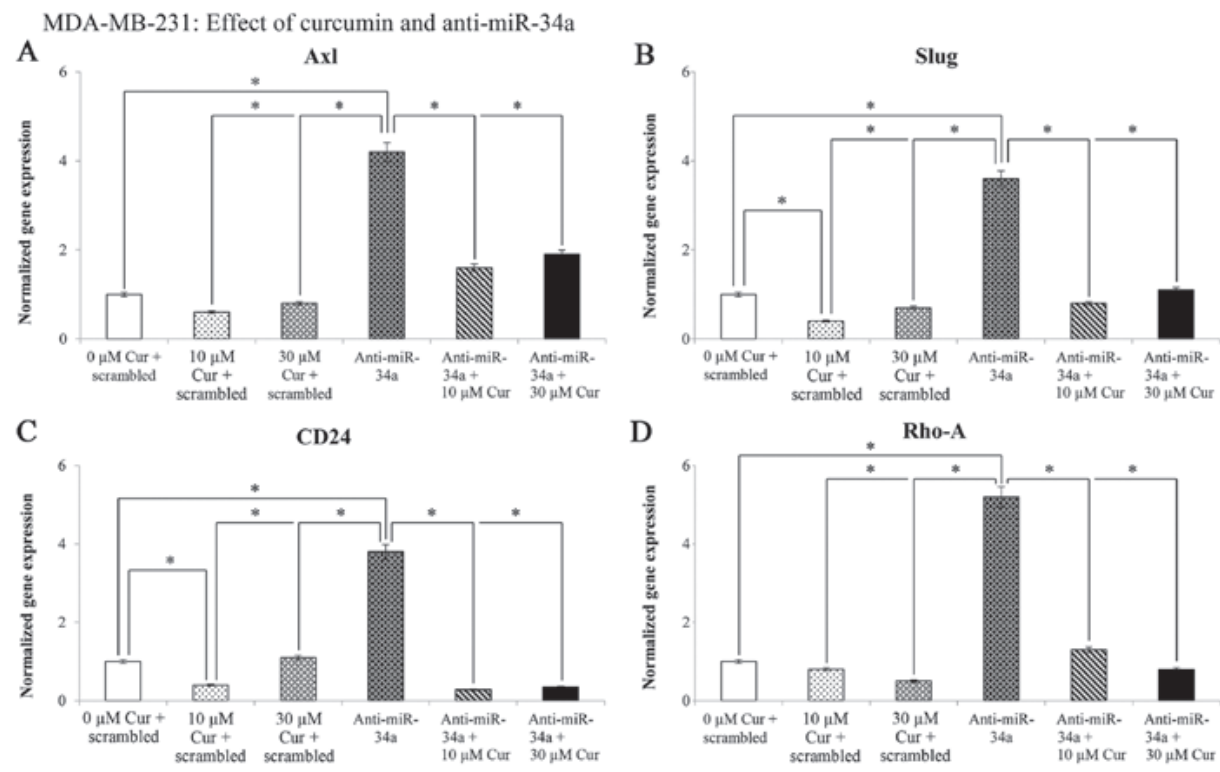

Figure 9. Graphs showing the effects of curcumin (Cur) (10 and $30 \mu \mathrm{M}$ for 48 h) on (A) Axl, (B) Slug, (C) CD24 and (D) Rho-A normalized gene expression, and transfection with anti-miR-34a analyzed by RT-qPCR. Bars represent the means \pm standard error of the mean $\left(\mathrm{n}=3\right.$; $\left.{ }^{*} \mathrm{P}<0.05\right)$.

cells transfected with the scramble control and the untreated cells.

The normalized gene expression levels of genes that code for proteins involved in EMT in the MDA-MB-231 cell line following transfection with anti-miR-34a are shown in Fig. 8B-E. miR-34a knockdown significantly $(\mathrm{P}<0.001)$ increased $A x l$ expression after 48 and $72 \mathrm{~h}$ of transfection (28 and 50\%, respectively) (Fig. 8B). miR-34a knockdown also significantly increased Slug gene expression after 24, 48 and $72 \mathrm{~h}$ of transfection $(155,452,226 \%$, respectively; $24 \mathrm{~h}, \mathrm{P}<0.005 ; 48$ and $72 \mathrm{~h}, \mathrm{P}<0.001$ ) (Fig. 8C). Following miR-34a knockdown, a significant $(\mathrm{P}<0.001)$ increase was also observed in $C D 24$ gene expression after $48 \mathrm{~h}$ and after $72 \mathrm{~h}$ of transfection (179 and 325\%, respectively) (Fig. 8D). miR-34a knockdown also significantly $(\mathrm{P}<0.001)$ increased $R h o-A$ gene expression (43\%) after $72 \mathrm{~h}$ of transfection (Fig. 8E). 

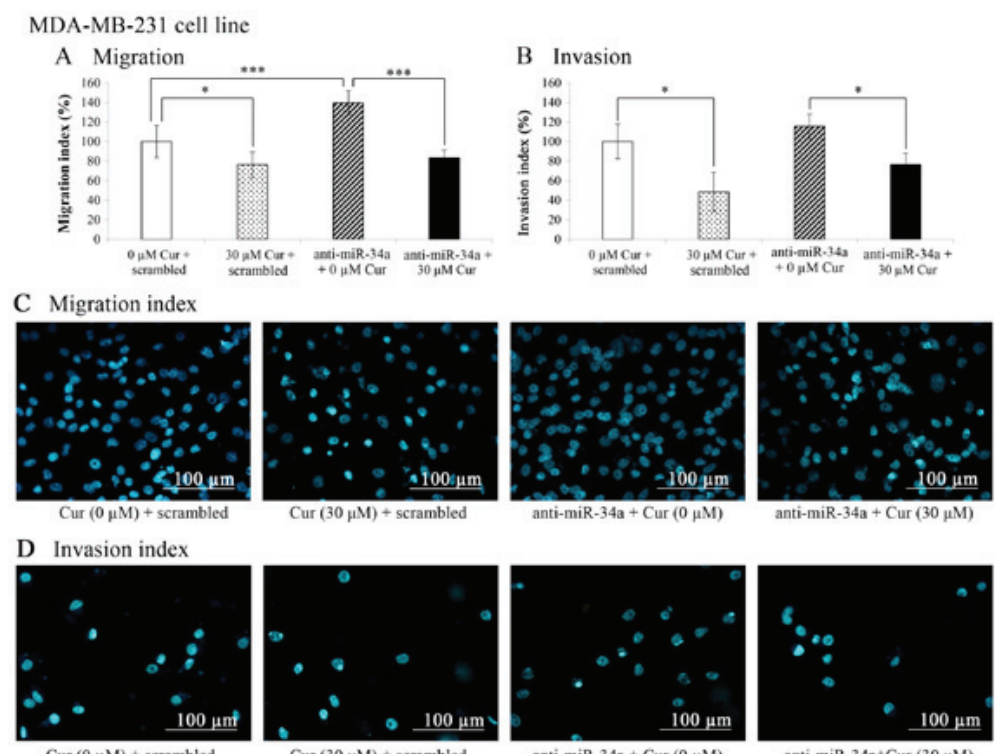

E Transfection efficiency

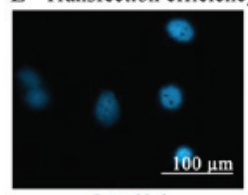

Scrambled

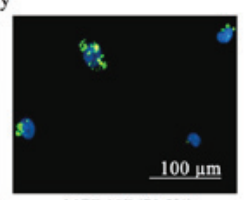

MCF-10F (70.5\%)

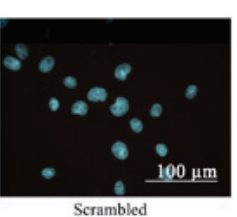

anti-miR-34a+Cur $(30 \mu \mathrm{M})$

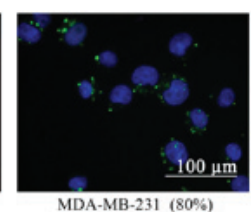

Figure 10. Graphs showing the effect of curcumin (Cur) (30 $\mu \mathrm{M}$ for $48 \mathrm{~h})$ and anti-miR-34a on (A) migration and (B) invasion in the MDA-MB-231 cell line. Bars represent the means \pm standard error of migration (\%) and invasion (\%) of MDA-MB-231, Cur, anti-miR-34a, and Cur plus anti-miR-34a (n=3; " $\mathrm{P}<0.05$, ${ }^{* * *} \mathrm{P}<0.001$ ). Representative images of $(\mathrm{C})$ migration index and (D) invasion index. (E) Transfection efficiency in the MCF-10F and MDA-MB-231 cell lines.

The effects of treatment with 10 and $30 \mu \mathrm{M}$ curcumin on Axl, Slug, CD24 and Rho-A gene expression are presented in Fig. 9. The results revealed a significant $(\mathrm{P}<0.05)$ decrease in Axl (39\%), Slug (57\%), CD24 (62\%) and Rho-A (53\%) gene expression following transfection with the negative control (scramble) in comparison with the untreated control cells $(0 \mu \mathrm{M}$ cur + scrambled $)$. Transfection with anti-miR-34a increased the expression levels of the Axl, Slug, CD24 and Rho-A genes (304, 260, 282 and 430\%, respectively). However, following treatment with curcumin and miR-34a knockdown, a significant $(\mathrm{P}<0.05)$ decrease was observed in the levels of the examined genes.

Effects of the blockade of miR-34a on the migratory and invasive capabilities of the MDA-MB-231 cell line. The results of the migration and invasion assays carried out in a Boyden chamber, as indicated in the graphs depicted in Fig. 10A and B revealed that curcumin $(30 \mu \mathrm{M}$ for $48 \mathrm{~h})$ significantly $(\mathrm{P}<0.05)$ decreased the migration (23.7\%) and invasion (51.6\%) of the MDA-MB-231 cell line in comparison with the untreated control cells $(0 \mu \mathrm{M}$ cur + scrambled $)$. On the other hand, when the cells were transfected with anti-miR-34a (Fig. 10A), cell migration significantly $(\mathrm{P}<0.001)$ increased in comparison with the untreated control $(0 \mu \mathrm{M}$ cur + scrambled $)$. Curcumin plus anti-miR-34a significantly $(\mathrm{P}<0.001)$ decreased the migration of the MDA-MB-231 cell line in comparison with the cells treated with anti-miR-34a alone. The percentage of migrated treated cells treated with curcumin was lower than that of the untreated control following transfection with anti-miR-34a. Representative images of the migratory capabilities of the
MDA-MB-231 cell line following treatment with curcumin and miR-34a blockade are shown in Fig. 10C.

Curcumin also significantly $(\mathrm{P}<0.05)$ decreased $(39.1 \%)$ cell invasion. The invasive capabilities of the cells were significantly $(\mathrm{P}<0.05)$ decreased in the cells transfected with anti-miR-34a and treated with curcumin compared with the cells treated with anti-miR-34a alone. Curcumin significantly $(\mathrm{P}<0.05)$ decreased cell invasion to the level of the control ( $0 \mu \mathrm{M}$ cur + scrambled $)$ when miR-34a was blocked and the cells were treated with curcumin. Representative images of the invasive capabilities of the MDA-MB-231 cell line following treatment with curcumin and the miR-34a blockade are shown in Fig. 10D.

In addition, transfection conditions were standardized by determining the transfection efficiency using a negative control (scrambled) that was previously marked by using fluorescence. As shown in Fig. 10E, the transfection efficiency was $70.5 \%$ in the MCF-10F and $80 \%$ in the MDA-MB-231 cell line in comparison with their respective controls.

\section{Discussion}

Studies have reported that curcumin possesses antioxidant, anti-proliferative, anti-migratory and apoptotic effects in several types of human cancers $(32,33,35)$. We have previously demonstrated such effects in breast cell lines and it has been corroborated by other authors in different cancers $(34,35,37,41)$. The present study demonstrated that curcumin acted upon $A x l$, Slug, CD24, genes implicated in EMT, as well as on Rho-A in a non-malignant MCF-10F and a malignant MDA-MB-231 
cell line. As regards the fact that the MDA-MB-231 cells were more sensitive to low concentrations of curcumin, whereas at $30 \mu \mathrm{M}$ the effect on gene expression was lost probably due to the negative ER and ERB2 receptors that render the cells to behave differently in comparison with a non-malignant cell line, as the MCF-10F cell line.

Curcumin also affected miRNAs as a regulator of genes implicated in EMT and $R h o-A$, affecting migration and invasion independent of their ER, PgR and HER2 receptors. Curcumin decreased Axl, Slug, CD24 and Rho-A gene and protein expression in the MCF-10F cell line when compared to the untreated control cells. It has been previously demonstrated that Slug and $A x l$ induce EMT and regulate several aspects of this process $(42,43)$. These results are in agreement with the downregulation of $A x l$ reversing EMT in mesenchymal normal human mammary epithelial cells that regulated breast cancer stem cell renewal $(44,45)$.

In a previous study, we examined the effects of curcumin on breast carcinogenesis in an established in vitro experimental model of breast cancer (termed the Alpha-model) (46); we examined the effects of curcumin on EMT in breast cancer cells transformed by low concentrations of alpha particles and estrogen. This in vitro experimental model was developed by the exposure of the MCF-10F immortalized breast epithelial cell line to low radiation concentrations of high linear energy transfer (LET) $\alpha$-particles $(150 \mathrm{keV} / \mu \mathrm{m})$ followed by culture in the presence of $17 \beta$-estradiol (estrogen). Three difference cell lines were used, namely the MCF-10F (normal), the Alpha5 (pre-tumorigenic) and the Tumor2 cells derived from Alpha5 injected into the nude mice. It has been demonstrated (36) that curcumin influences changes in the levels of genes associated with EMT and which are situated at the core of several signaling pathways known to mediate the transition and such results indicated that curcumin decreased the protein expression levels of N-cadherin, $\beta$-catenin, Slug, AXL, Twist1, Vimentin and Fibronectin, independently of the positivity of the markers in these cell lines. Curcumin was also shown to decrease the migratory and invasive capabilities of the cells compared with their respective controls. Thus, it was concluded that curcumin was able to prevent or attenuate cancer progression through the disruption of the EMT processes (36), i.e., by affecting the gene expression E-cadherin and other genes in the MDA-MB-231 cells. In another study, it was demonstrated that curcumin decreased the expression of levels of genes (such as E-cadherin, $N$-cadherin, ZEB2, Twist1, Slug, $A X L$, vimentin, STAT-3, and fibronectin) involved in the EMT process in the Tumor2 cells when compared to the respective control. In addition, it was demonstrated that curcumin altered the levels of the p53 and caveolin-1 genes, as well as those of the apoptotic genes, caspase- 3 and caspase- 8 , as well cyclin $D 1$ and $N F-\kappa B$. These changes in expression levels led to a decrease in the migratory and invasive capabilities of such a cell line (38). This suggests that curcumin may affect the apoptosis and metastatic properties of malignant cells, exerting antitumor effects on breast cancer cells transformed by low concentrations of $\alpha$-particles and estrogen in vitro (38).

The miR-34 family was originally cloned and characterized in 2007 as a p53 target gene $(47,48)$. Soon thereafter, it became evident this miRNA played a main role as a master regulator of tumor suppression. Notably, the overexpression of
miR-34 directly and indirectly suppresses several oncogenes, resulting in an increase in cancer cell death (including cancer stem cells), and in the inhibition of metastasis. Moreover, the expression of miR-34 is known to be deregulated in several types of human cancers (49). In 2013, a miR-34 mimic became the first miRNA to reach phase 1 clinical trials (50).

Others (31) have reported that the regulation of miRNAs by natural agents is a novel new strategy for the treatment of cancer. In the study by Tarasov et al (2007), the differential regulation of miRNAs by 53 revealed by massively parallel sequencing revealed miR-34a as a target of p53 that induces apoptosis and G1-arrest. Thus, miR-34a suppressed transcription factors implicated in EMT, thus inhibiting metastasis (51). It has also been demonstrated that miR-34 and SNAIL form a double-negative feedback loop to regulate EMT (52). Axl targeted by miR-34a is well known and its expression is significantly associated with metastatic cancer of an advanced clinical stage. Of note, Axl is associated with a poor prognosis in different types of cancer (53).

In this study, the effects of curcumin on the expression of EMT-associated genes in MCF-the $10 \mathrm{~F}$ cell line were examined following the knockdown miR-34a. The transfection conditions were standardized by determining the transfection efficiency using a negative control (scrambled) by using fluorescence methods in the MCF-10F and in MDA-MB-231 cell lines in comparison with the control. The results revealed that curcumin decreased $A x l$, Slug, CD24, and Rho-A gene expressions after transfection with negative control (scrambled). Transfection with anti-miR-34a increased the expression of these genes. However, the cells in which miR-34a was knocked down were also treated with curcumin, a decrease in the expression of these genes was observed in comparison to the untreated cells. The knockdown of miR-34a expression in the MDA-MB-231 cell line increased Axl, Slug, CD24 and Rho-A gene expression. However, when curcumin was added to the cells in which miR-34a was knocked down, there was a decrease in anti-miR-34a plus curcumin-treated group in comparison to the untreated cells. The effects of anti-miR-34a transfection were validated by using the Anti-miR ${ }^{\mathrm{TM}}$ negative control. This is a random commercial molecule which has been extensively tested in human cell lines by us and others. In addition, it has been widely demonstrated that this control does not alter known functions of miRNAs and mRNAs (54-57). In this study, the results suggested that this scrambled sequence did not affect the expression of miR-34a or that of EMT-related genes evaluated at 24 and $48 \mathrm{~h}$ post-transfection in the MCF-10F and MDA-MB-231 cell lines. Although other exposure times were analyzed on EMT-related genes without using this scrambled group, the lack of this control did not alter our general conclusions as the main focus of this study was on the rapid-response phenotypic changes related to EMT, such as cell migration and invasion. Therefore, only short-time exposures to curcumin and anti-miR-34a were evaluated. However, this rationale could be an important limitation if these results are extrapolated to a different context, such as biomedical applications. In this scenario, robust in vivo assays are warranted to validate the anti-miR-34a administration mechanisms and the integrity of curcumin over time. Currently, nanotechnology offers novel materials that guarantee high efficiency in the supply of therapeutic agents; for example, 
gold nanostructures, dextran nanobubbles or nanoemulsions are emerging tools that improve aqueous solubility and the supply of curcumin to the tissue of interest (58-61). Similarly, RNA nanotechnology to administer anti-miRNA is already being validated in cancer (62). Therefore of this study may provide a novel strategy with which to combat breast cancer if nanomaterials are implemented in improving delivery over time and the specificity of therapeutic agents.

Previously, we determined the potential effects of curcumin on EMT in relation to migration and invasion and compared the Tumor2 and MDA-MB-231 cell lines $(36,38)$. Curcumin inhibited the migration and invasive capabilities through EMT in the breast cancer cells. It has also been found that curcumin inhibits the proliferation and invasion of different types of cancer (41). In the present study, curcumin decreased cell migration and invasion in the control-transfected MCF-10F and MDA-MB-231 cell lines in comparison with the untreated cells. When these cells were transfected with anti-miR-34a, cell migration increased.

miRNAs are known as important targets for curcumin $(63,64)$. These molecules can affect numerous cellular and molecular events (65-70), since it has been found that curcumin can affect the chemoresistance of cancer cells by changing the expression of certain miRNAs. Thus, curcumin functions as a master regulator of the genome by modulating the expression of thousands of genes, simultaneously controlling multiple signaling pathways $(43,71)$. The therapeutic use of miRNAs has been considered for all these reasons. However, further studies are warranted using additional cell lines.

The results of this study indicated that curcumin decreased the migration of the MDA-MB-231 cell line. When these cells were transfected with anti-miR-34a, cell migration increased. However, curcumin decreased the migration of the MDA-MB-231 cell line transfected with anti-miR-34a in comparison with the control untreated cells. The percentage of migrated treated cells with curcumin was lower than the control following transfection with anti-miR-34a. This suggests that additional mechanisms may be involved in mediating the observed effects of curcumin on the invasive and migratory abilities of these cells.

An increasing number of preclinical studies support the hypothesis that curcumin may be a promising anticancer drug. In vitro studies require higher amounts of chemical compounds to analyze different physiological effects on cells; thus, the 10 and $30 \mu \mathrm{M}$ concentrations of curcumin were used in this study. However, the poor bioavailability has limited the efficacy of curcumin in clinical trials, and plasma curcumin levels remain low $(\mathrm{ng} / \mathrm{ml})$ despite patients taking gram doses of curcumin, which is insufficient to yield the anticancer benefits of curcumin. This issue has been resolved by the development of highly bioavailable forms of curcumin (THERACURMIN ${ }^{\circledR}$ ), and higher plasma curcumin levels can now be achieved without increased toxicity in patients. At the present time, some researchers are testing this substance in nanoparticles to improve the bioavailability (72).

Chemotherapy is known as one of the effective therapeutic approaches for the treatment of a wide variety of cancers $(73,74)$. Recently, the regulation of miRNAs by natural, nontoxic chemopreventive agents, including curcumin has been described. Over the past decade, research on curcumin for its chemoprophylactic and anti-inflammatory properties has been increasing. Fadus et al (2017) reviewed that trials on curcumin trials are mainly focused on colorectal cancer, hepatocellular carcinoma and several other tissues (75). The authors indicated that there were at least 12 active clinical trials of curcumin in the USA, Israel and Hong Kong. As of July 2012, there have been observations from 67 clinical trials that have been published, with another 35 clinical trials which were in progress at that time (75).

In conclusion, the present study demonstrated that the $A x l$, Slug and CD24 genes were implicated in EMT. Rho-A was also found to be involved in the migration and invasion of the MCF-10F and MDA-MB-231 cell lines. Curcumin affected the expression levels of genes involved in EMT and invasion by controlling miR-34a expression in the breast cell lines. Curcumin acted upon miRNAs as a regulator of genes implicated in EMT, as well as on Rho-A, affecting the migration and invasion of the non-malignant $\mathrm{MCF}-10 \mathrm{~F}$ and malignant MDA-MB-231 breast cancer cell lines, independent of their ER, PgR and HER2 receptor status; these cell lines are both negative for such receptors.

Therefore, it is demonstrated that natural agents have the ability to inhibit cancer progression, increase drug sensitivity, reverse EMT and prevent metastasis through the modulation of miRNAs. These findings may provide a novel therapeutic approach for cancer treatment, particularly when used in combination with conventional therapeutics (31). Furthermore, to the best of our knowledge, this the first study to examine the effects of curcumin on Rho-A and genes involved in EMT, such as $A x l$, Slug and CD24. It is demonstrated that curcumin prevents the migration and invasion of breast cells by targeting miR-34a as a regulator of the above-mentioned genes.

\section{Acknowledgements}

The authors would like to acknowledge the technical support provided by Mr. Leodán A. Crispin, Mr. Richard Ponce Cusi, Ms. Guiliana Rojas and Mrs. Georgina Vargas Marchant from Universidad de Tarapacá.

\section{Funding}

The present study was supported by FONDECYT \#1120006 (to GMC), grant UTA-MINEDUC (UTA1117, to GMC), FONDECYT \#1161219 (to FA), FONDECYT \#3190744 (to JPM) and CONICYT-FONDAP \#15130011 (to FA).

\section{Availability of data and materials}

The datasets used during the present study are available from the corresponding author upon reasonable request.

\section{Authors' contributions}

MG and GMC conceived and designed the study. MG, UK, FA, JPM, TCB and GMC performed the experiments. MG and GMC wrote the manuscript. GMC, UK, and FA, JPM and TCB edited and reviewed the manuscript. All authors have read and approved the manuscript and agree to be accountable 
for all aspects of the research in ensuring that the accuracy or integrity of any part of the work is appropriately investigated and resolved.

\section{Ethics approval and consent to participate}

Not applicable.

\section{Patient consent for publication}

Not applicable.

\section{Consent for publication}

The authors declare that they have no competing interests.

\section{References}

1. Ferlay J, Soerjomataram I, Dikshit R, Eser S, Mathers C, Rebelo M, Parkin DM, Forman D and Bray F: Cancer incidence and mortality worldwide: Sources, methods and major patterns in GLOBOCAN 2012. Int J Cancer 136: E359-E386, 2015.

2. Sethi $\mathrm{N}$ and Kang Y: Unravelling the complexity of metastasis - molecular understanding and targeted therapies. Nat Rev Cancer 11: 735-748, 2011.

3. Chaffer CL and Weinberg RA: A perspective on cancer cell metastasis. Science 331: 1559-1564, 2011.

4. Howlader N, Noone AM, Krapcho M, Miller D, Bishop K, Kosary CL, Yu M, Ruhl J, Tatalovich Z, Mariotto A, et al (eds): SEER Cancer Statistics Review, 1975-2014. National Cancer Institute. Bethesda, MD, 2016. https://seer.cancer gov/csr/1975 2014/. Accessed April 2017.

5. Kalluri R and Neilson EG: Epithelial-mesenchymal transition and its implications for fibrosis. J Clin Invest 112: 1776-1784, 2003.

6. Graham DK, DeRyckere D, Davies KD and Earp HS: The TAM family: Phosphatidylserine sensing receptor tyrosine kinases gone awry in cancer. Nat Rev Cancer 14: 769-785, 2014.

7. Kirane A, Ludwig KF, Sorrelle N, Haaland G, Sandal T, Ranaweera R, Toombs JE, Wang M, Dineen SP, Micklem D, et al: Warfarin Blocks Gas6-Mediated Axl Activation Required for Pancreatic Cancer Epithelial Plasticity and Metastasis. Cancer Res 75: 3699-3705, 2015.

8. Linger RM, Keating AK, Earp HS and Graham DK: TAM receptor tyrosine kinases: Biologic functions, signaling, and potential therapeutic targeting in human cancer. Adv Cancer Res 100: 35-83, 2008.

9. Dunne PD, McArt DG, Blayney JK, Kalimutho M, Greer S, Wang T, Srivastava S, Ong CW, Arthur K, Loughrey M, et al: AXL is a key regulator of inherent and chemotherapy-induced invasion and predicts a poor clinical outcome in early-stage colon cancer. Clin Cancer Res 20: 164-175, 2014.

10. Hajra KM, Chen DY and Fearon ER: The SLUG zinc-finger protein represses E-cadherin in breast cancer. Cancer Res 62 . 1613-1618, 2002

11. Castro Alves C, Rosivatz E, Schott C, Hollweck R, Becker I, Sarbia M, Carneiro F and Becker KF: Slug is overexpressed in gastric carcinomas and may act synergistically with SIP1 and Snail in the down-regulation of E-cadherin. J Pathol 211: 507-515, 2007.

12. Ye Y, Xiao Y, Wang W, Yearsley K, Gao JX, Shetuni B and Barsky SH: ERalpha signaling through slug regulates E-cadherin and EMT. Oncogene 29: 1451-1462, 2010.

13. Atmaca A, Wirtz RW, Werner D, Steinmetz K, Claas S Brueck1 WM, Jäger E and Al-Batran SE: SNAI2/SLUG and estrogen receptor mRNA expression are inversely correlated and prognostic of patient outcome in metastatic non-small cell lung cancer. BMC Cancer 15: 300, 2015.

14. Pirruccello SJ and LeBien TW: The human B cell-associated antigen CD24 is a single chain sialoglycoprotein. J Immunol 136 3779-3784, 1986

15. Daniel L, Lechevallier E, Bouvier C, Coulange C and Pellissier JF: Adult mesoblastic nephroma. Pathol Res Pract 196: $135-139,2000$
16. 16. Kristiansen G, Denkert C, Schlüns K, Dahl E, Pilarsky C and Hauptmann S: CD24 is expressed in ovarian cancer and is a new independent prognostic marker of patient survival. Am J Pathol 161: 1215-1221, 2002.

17. Jacob J, Bellach J, Grützmann R, Alldinger I, Pilarsky C, Dietel M and Kristiansen G: Expression of CD24 in adenocarcinomas of the pancreas correlates with higher tumor grades. Pancreatology 4: 454-460, 2004.

18. Kristiansen G, Winzer KJ, Mayordomo E, Bellach J, Schlüns K, Denkert C, Dahl E, Pilarsky C, Altevogt P, Guski H, et al: CD24 expression is a new prognostic marker in breast cancer. Clin Cancer Res 9: 4906-4913, 2003.

19. Yu LLG and Gu JY: Advances in the role of Rho sub-family in tumor invasion. Fudan Univ J Med Sci 37: 617-619, 2010.

20. Hall A: Rho GTPases and the actin cytoskeleton. Science 279: 509-514, 1998

21. DerMardirossian C and Bokoch GM: GDIs: Central regulatory molecules in Rho GTPase activation. Trends Cell Biol 15: 356-363, 2005

22. Olofsson B: Rho guanine dissociation inhibitors: Pivotal molecules in cellular signalling. Cell Signal 11: 545-554, 1999.

23. Fritz G, Brachetti C, Bahlmann F, Schmidt M and Kaina B: Rho GTPases in human breast tumours: Expression and mutation analyses and correlation with clinical parameters. Br J Cancer 87: 635-644, 2002

24. Burbelo P, Wellstein A and Pestell RG: Altered Rho GTPase signaling pathways in breast cancer cells. Breast Cancer Res Treat 84: 43-48, 2004.

25. Zaravinos A: The Regulatory Role of MicroRNAs in EMT and Cancer. J Oncol 2015: 865816, 2015.

26. Ng EK, Wong CL, Ma ES and Kwong A: MicroRNAs as New Players for Diagnosis, Prognosis, and Therapeutic Targets in Breast Cancer. J Oncol 2009: 305420, 2009.

27. Pichler M and Calin GA: MicroRNAs in cancer: From developmental genes in worms to their clinical application in patients. $\mathrm{Br}$ J Cancer 113: 569-573, 2015.

28. Croce CM: Causes and consequences of microRNA dysregulation in cancer. Nat Rev Genet 10: 704-714, 2009.

29. Hermeking H: The miR-34 family in cancer and apoptosis. Cell Death Differ 17: 193-199, 2010.

30. Li Y, Kong D, Wang Z and Sarkar FH: Regulation of microRNAs by natural agents: An emerging field in chemoprevention and chemotherapy research. Pharm Res 27: 1027-1041, 2010.

31. Sethi S, Li Y and Sarkar FH: Regulating miRNA by natural agents as a new strategy for cancer treatment. Curr Drug Targets 14: 1167-1174, 2013.

32. Mirzaei H, Shakeri A, Rashidi B, Jalili A, Banikazemi Z and Sahebkar A: Phytosomal curcumin: A review of pharmacokinetic, experimental and clinical studies. Biomed Pharmacother 85: 102-112, 2017.

33. Kuttan R, Bhanumathy P, Nirmala K and George MC: Potential anticancer activity of turmeric (Curcuma longa). Cancer Lett 29: 197-202, 1985.

34. Calaf GM, Echiburú-Chau C, Roy D, Chai Y, Wen G and Balajee AS: Protective role of curcumin in oxidative stress of breast cells. Oncol Rep 26: 1029-1035, 2011.

35. Calaf GM: Curcumin, oxidative stress and breast cancer. In: Oxidative stress and dietary antioxidants. Preedy VR (ed). Elsevier Inc., London, pp159-169, 2014.

36. Gallardo M and Calaf GM: Curcumin and epithelial-mesenchymal transition in breast cancer cells transformed by low doses of radiation and estrogen. Int J Oncol 48: 2534-2542, 2016.

37. Echiburú-Chau C, Roy D and Calaf GM: Metastatic suppressor CD44 is related with oxidative stress in breast cancer cell lines. Int J Oncol 39: 1481-1489, 2011.

38. Gallardo M and Calaf GM: Curcumin inhibits invasive capabilities through epithelial mesenchymal transition in breast cancer cell lines. Int J Oncol 49: 1019-1027, 2016.

39. Calaf GM and Abarca-Quinones J: Ras protein expression as a marker for breast cancer. Oncol Lett 11: 3637-3642, 2016.

40. Livak KJ and Schmittgen TD: Analysis of relative gene expression data using real-time quantitative PCR and the 2(-Delta Delta C(T)) Method. Methods 25: 402-408, 2001.

41. Kunnumakkara AB, Anand P and Aggarwal BB: Curcumin inhibits proliferation, invasion, angiogenesis and metastasis of different cancers through interaction with multiple cell signaling proteins. Cancer Lett 269: 199-225, 2008.

42. Alves CC, Carneiro F, Hoefler H and Becker KF: Role of the epithelial-mesenchymal transition regulator Slug in primary human cancers. Front Biosci 14: 3035-3050, 2009. 
43. Lewis BP, Burge CB and Bartel DP: Conserved seed pairing, often flanked by adenosines, indicates that thousands of human genes are microRNA targets. Cell 120: 15-20, 2005.

44. Zhao Y, Sun X, Jiang L, Yang F, Zhang Z and Jia L: Differential expression of $\mathrm{Axl}$ and correlation with invasion and multidrug resistance in cancer cells. Cancer Invest 30: 287-294, 2012.

45. Vuoriluoto K, Haugen H, Kiviluoto S, Mpindi JP, Nevo J, Gjerdrum C, Tiron C, Lorens JB and Ivaska J: Vimentin regulates EMT induction by Slug and oncogenic H-Ras and migration by governing Axl expression in breast cancer. Oncogene 30: 1436-1448, 2011.

46. Calaf GM and Hei TK: Establishment of a radiation- and estrogen-induced breast cancer model. Carcinogenesis 21 : 769-776, 2000

47. Raver-Shapira N, Marciano E, Meiri E, Spector Y, Rosenfeld N, Moskovits N, Bentwich Z and Oren M: Transcriptional activation of miR-34a contributes to p53-mediated apoptosis. Mol Cell 26 731-743, 2007.

48. Chang TC, Wentzel EA, Kent OA, Ramachandran K, Mullendore M, Lee KH, Feldmann G, Yamakuchi M, Ferlito M, Lowenstein CJ, et al: Transactivation of miR-34a by p53 broadly influences gene expression and promotes apoptosis. Mol Cell 26: 745-752, 2007.

49. Agostini M and Knight RA: miR-34: From bench to bedside. Oncotarget 5: 872-881, 2014

50. Beg MS, Brenner AJ, Sachdev J, Borad M, Kang YK, Stoudemire J, Smith S, Bader AG, Kim S and Hong DS: Phase I study of MRX34, a liposomal miR-34a mimic, administered twice weekly in patients with advanced solid tumors. Invest New Drugs 35: 180-188, 2017.

51. Tarasov V, Jung P, Verdoodt B, Lodygin D, Epanchintsev A Menssen A, Meister G and Hermeking H: Differential regulation of microRNAs by 53 revealed by massively parallel sequencing: miR-34a is a 53 target that induces apoptosis and G1-arrest. Cell Cycle 6: 1586-1593, 2007.

52. Siemens H, Jackstadt R, Hünten S, Kaller M, Menssen A, Götz U and Hermeking H: miR-34 and SNAIL form a double-negative feedback loop to regulate epithelial-mesenchymal transitions. Cell Cycle 10: 4256-4271, 2011.

53. Mudduluru G, Ceppi P, Kumarswamy R, Scagliotti GV, Papotti $\mathrm{M}$ and Allgayer $\mathrm{H}$ : Regulation of Axl receptor tyrosine kinase expression by miR-34a and miR-199a/b in solid cancer. Oncogene 30: 2888-2899, 2011.

54. Komina A, Palkina N, Aksenenko M, Tsyrenzhapova S and Ruksha T: Antiproliferative and Pro-Apoptotic Effects of MiR-4286 Inhibition in Melanoma Cells. PLoS One 11: e0168229, 2016.

55. Wang X, Zhang Y, Fu Y, Zhang J, Yin L, Pu Y and Liang G: MicroRNA-125b may function as an oncogene in lung cancer cells. Mol Med Rep 11: 3880-3887, 2015.

56. Mizuno R, Chatterji P, Andres S, Hamilton K, Simon L, Foley SW, Jeganathan A, Gregory BD, Madison B and Rustgi AK: Differential Regulation of LET-7 by LIN28B Isoform-Specific Functions. Mol Cancer Res 16: 403-416, 2018.

57. Lemecha M, Morino K, Imamura T, Iwasaki H, Ohashi N, Ida $S$, Sato D, Sekine O, Ugi S and Maegawa H: MiR-494-3p regulates mitochondrial biogenesis and thermogenesis through PGC1-o signalling in beige adipocytes. Sci Rep 8: 15096, 2018.

58. Inostroza-Riquelme M, Vivanco A, Lara P, Guerrero S, Salas-Huenuleo E, Chamorro A, Leyton L, Bolaños K, Araya E, Quest AFG, et al: Encapsulation of Gold Nanostructures and Oil-in-Water Nanocarriers in Microgels with Biomedical Potential. Molecules 23: E1208, 2018.

59. Bessone F, Argenziano M, Grillo G, Ferrara B, Pizzimenti S, Barrera G, Cravotto G, Guiot C, Stura I, Cavalli R, et al: Low-dose curcuminoid-loaded in dextran nanobubbles can prevent metastatic spreading in prostate cancer cells. Nanotechnology 30 214004, 2019.
60. Guerrero S, Inostroza-Riquelme M, Contreras-Orellana P, Diaz-Garcia V, Lara P, Vivanco-Palma A, Cárdenas A, Miranda V, Robert P, Leyton L, et al: Curcumin-loaded nanoemulsion: A new safe and effective formulation to prevent tumor reincidence and metastasis. Nanoscale 10: 22612-22622, 2018.

61. Gera M, Sharma N, Ghosh M, Huynh DL, Lee SJ, Min T, Kwon T and Jeong DK: Nanoformulations of curcumin: An emerging paradigm for improved remedial application. Oncotarget 8: 66680-66698, 2017.

62. Yin H, Xiong G, Guo S, Xu C, Xu R, Guo P and Shu D: Delivery of Anti-miRNA for Triple-Negative Breast Cancer Therapy Using RNA Nanoparticles Targeting Stem Cell Marker CD133. Mol Ther 27: 1252-1261, 2019.

63. Momtazi AA, Shahabipour F, Khatibi S, Johnston TP, Pirro M and Sahebkar A: Curcumin as a MicroRNA Regulator in Cancer: A Review. Rev Physiol Biochem Pharmacol 171: 1-38, 2016.

64. Rabieian R, Boshtam M, Zareei M, Kouhpayeh S, Masoudifar A and Mirzaei H: Plasminogen Activator Inhibitor Type-1 as a Regulator of Fibrosis. J Cell Biochem 119: 17-27, 2018

65. Banikazemi Z, Haji HA, Mohammadi M, Taheripak G, Iranifar E, Poursadeghiyan M, Moridikia A, Rashidi B, Taghizadeh M and Mirzaei H: Diet and cancer prevention: Dietary compounds, dietary MicroRNAs, and dietary exosomes. J Cell Biochem 119: 185-196, 2018.

66. Saeedi Borujeni MJ, Esfandiary E, Taheripak G, Codoñer-Franch P, Alonso-Iglesias E and Mirzaei H: Molecular aspects of diabetes mellitus: Resistin, microRNA, and exosome. J Cell Biochem 119: 1257-1272, 2018.

67. Golabchi K, Soleimani-Jelodar R, Aghadoost N, Momeni F, Moridikia A, Nahand JS, Masoudifar A, Razmjoo H and Mirzaei H: MicroRNAs in retinoblastoma: Potential diagnostic and therapeutic biomarkers. J Cell Physiol 233: 3016-3023, 2018.

68. Mirzaei H, Khataminfar S, Mohammadparast S, Sales SS, Maftouh M, Mohammadi M, Simonian M, Parizadeh SM, Hassanian SM and Avan A: Circulating microRNAs as Potential Diagnostic Biomarkers and Therapeutic Targets in Gastric Cancer: Current Status and Future Perspectives. Curr Med Chem 23: 4135-4150, 2016.

69. Rashidi B, Hoseini Z, Sahebkar A and Mirzaei H: Anti-Atherosclerotic Effects of Vitamins D and E in Suppression of Atherogenesis. J Cell Physiol 232: 2968-2976, 2017.

70. Mirzaei H, Masoudifar A, Sahebkar A, Zare N, Sadri Nahand J, Rashidi B, Mehrabian E, Mohammadi M, Mirzaei HR and Jaafari MR: MicroRNA: A novel target of curcumin in cancer therapy. J Cell Physiol 233: 3004-3015, 2018.

71. Calin GA and Croce CM: MicroRNA signatures in human cancers. Nat Rev Cancer 6: 857-866, 2006.

72. Kanai M, Imaizumi A, Otsuka Y, Sasaki H, Hashiguchi M, Tsujiko K, Matsumoto S, Ishiguro H and Chiba T: Dose-escalation and pharmacokinetic study of nanoparticle curcumin, a potential anticancer agent with improved bioavailability, in healthy human volunteers. Cancer Chemother Pharmacol 69: 65-70, 2012.

73. Sinha D, Biswas J, Sung B, Aggarwal BB and Bishayee A: Chemopreventive and chemotherapeutic potential of curcumin in breast cancer. Curr Drug Targets 13: 1799-1819, 2012

74. Zhou S, Zhang S, Shen H, Chen W, Xu H, Chen X, Sun D, Zhong S, Zhao J and Tang J: Curcumin inhibits cancer progression through regulating expression of microRNAs. Tumour Biol 39: $1010428317691680,2017$.

75. Fadus MC, Lau C, Bikhchandani J and Lynch HT: Curcumin: An age-old anti-inflammatory and anti-neoplastic agent. J Tradit Complement Med 7: 339-346, 2016.

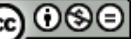

This work is licensed under a Creative Commons Attribution-NonCommercial-NoDerivatives 4.0 International (CC BY-NC-ND 4.0) License. 